Олег Рибчук,

Національний університет оборони України імені Івана Черняховського, м. Київ

ORCID ID 0000-0003-3966-8326

\title{
СУБ’ЄКТНІСТЬ ВИКЛАДАЧА ВИЩОЇ ВІЙСЬКОВОЇ ШКОЛИ
}

Стаття присвячена проблемі становлення викладача вищої військової школи, як суб'єкта педагогічної діяльності. На сьогоднішній день у контексті реформування Збройних Сил Украйни військова освіта набуває особливого значення, а до професійності викладача вищої військової школи висуваються високі вимоги. Досягнення високого рівня професійного розвитку військового педагога залежить від особистого ставлення до професії та власного самосприйняття у ній. У статті проаналізовано філософські, педагогічні та психологічні підходи до визначення сутнісних ознак суб'єктності. Визначені особистісні характеристики суб'єктності викладача вищої військової иколи. Результати дослідження дають можливість для напраџювання підходів до підготовки та підвищення кваліфікаиї військових викладачів, розвитку їх суб'єктності.

Ключові слова. Суб'єкт; суб'єктність; діяльність; активність; викладач; освіта; розвиток.

Постановка проблеми. Сучасне інформаційне суспільство характеризується зокрема й стрімким технічним розвитком, значним накопиченням інформації та швидким іiі обміном. В освітньому аспекті констатуємо швидке старіння навчального змісту, появу нових форм та технологій навчання із застосуванням нових інформаційних технологій. Зазначене вимагає від викладача вищої військової школи (далі ВВШ) постійного навчання, розвитку на професійному та особистісному рівнях.

Представлення викладача ВВШ 3 позиції суб'єкта педагогічної діяльності протиставляється розумінню його як пасивного учасника освітнього процесу, що відповідає на зовнішні стимули лише системою реакцій, є об’єктом освітньої системи. Останнє суперечить гуманістичним ідеям розуміння людини та актуалізує завдання 3'ясування сутності суб'єктності викладача ВВШ.

Суб'єктно-діяльнісний підхід в освіті виявився досить затребуваним, оскільки дозволяє визначити характеристики особистості професіонала, які дозволять йому розвиватися та успішно діяти за умов невизначеності, стрімких соціальних змін, інновацій у професійній діяльності.

Аналіз досліджень та публікацій. Проблема суб'єктності та суб'єкта діяльності була предметом значної кількості досліджень. Ї̈̈ у своїх працях розглядали Б. Ананьєв, Дж. Дьюї, Е. Кант, А. Леонтьєв, Ч. Пірс, С. Рубінштейн, Ж. Сартр, Г. Сковорода, Е. Тоффлер, К. Ясперс та інші. Питанням суб'єктного підходу до розвитку особистості присвячені праці К. Абульханової-Славської, Б. Ананьєва, Г. Балла, А. Брушлинського, Г. Костюка, С. Максименка, В. Петровського та інших. Розвитку суб'єктності військових фахівців присвятили свої праці М. Кришталь, В. Король, В. Осьодло, В. Ягупов та інші. 
Незважаючи на значну кількість досліджень присвячених проблемі суб'єктності, суб'єктність викладача ВВШ не була предметом окремого педагогічного дослідження.

Метою дослідження $є$ 3'ясування сутнісних характеристик суб' єктності викладача ВВШ.

Методи дослідження. Дослідження суб'єктності викладачів вищої військової школи проводилося шляхом теоретичного аналіз філософських та наукових джерел, що присвячені питанням особистісного розвитку людини та в яких розкривається сутність суб'єктно-діяльнісного підходу; узагальнення та систематизація існуючих поглядів на визначення поняття та сутнісних характеристик суб'єктності; синтез та екстраполяція наукових підходів до визначення суб' єктності на предмет діяльності викладача ВВШ.

\section{Виклад основного матеріалу.}

Сучасне розуміння суб'єктності викладача ВВШ проявляється у його здатності бути суб' єктом педагогічної діяльності. Таке розуміння вказує на те, що поняття «суб' єктність» неподільно пов'язане 3 поняттям «суб'єкт», а тому для 3'ясування сутнісних характеристик суб'єктності викладачів ВВШ слід визначити зміст ключових понять.

Укладачі Філософського енциклопедичного словника тлумачать поняття «суб' єкт», з різних позицій, зокрема - у широкому розумінні особа, ..., що здійснює властиву їй діяльність, спрямовану на практичне перетворення предметної дійсності, теоретичне і духовно-практичне освоєння об'єктивної реальності; носій означених якостей, що уможливлюють виконання ним суспільно значущих функцій.

Необхідними рисами суб'єкту є: предметність, що означає бути предметним утворенням і діяти тільки предметним способом; свідомість, яка відображає реальність, зорієнтовує суб'єкта у навколишньому середовищі та визначає мету діяльності; активність, яка забезпечує провідну роль суб'єкта у взаємодії з навколишнім світом (ігнорування активності суб'єкта характерне для споглядального матеріалізму); воля, наявність якої робить предметну діяльність здійсненною і забезпечує досягнення поставленої мети. [7, с. 612613].

Отже, провідними сутнісними характеристиками особи, як суб'єкта певної діяльності виступають: предметність, активність та воля.

Методологічним підгрунтям ідеї суб'єктності виступають також провідні ідеї представників екзистенціалізму. Зокрема Ж. Сартра, А. Камю, К. Ясперса, М. Гайдегера та ін. Всіх їх об'єднує переконання у тому, що існування передує сутності і тому слід виходити від суб'єкта в обгрунтуванні сутності людини, що проявляється в їі діяльності (праксисі).

Ж. Сартр стверджував, що: «Людина просто існує, і вона не тільки така, якою себе уявляє, але й така, якою хоче стати. I оскільки вона уявляє себе вже після того, як починає існувати, і проявляє волю вже після того, як починає існувати, і після цього пориву до існування, то вона є лише тим, що сама з себе робить. ... людина перш за все існує, людина - істота, яка тяжіє до 
майбутнього і усвідомлює, що вона проектує себе у майбутнє. Людина - це перш за все проект, який переживається суб'єктивно...» [6, с. 612].

Схожої до екзистенціалістів позиції дотримується Е. Дюркгейм. У своїх працях він досліджує особливості індивідуального сприйняття індивідом соціальних норм, що нав'язує суспільство, де зазначає, що «кожен 3 нас в певній мірі створює собі власну мораль, власну релігію, власну техніку» [2, с. 405].

Ідея проектування людиною себе у майбутнє і усвідомлене втілення своїх уявлень про власну професійну діяльність у життя - має знайти свою реалізацію у підходах до професійного навчання. Зокрема, в освітньому процесі вона реалізується у педагогічному проектуванні та суб'єктнодіяльнісному підході до організації навчання.

Розуміння вчених людини, як власного проекту в майбутнє, наштовхує на думку, що досягнення людиною успіху в професійній діяльності (зокрема викладача ВВШ) залежить перш за все від сформованого усвідомленого образу себе у професійній діяльності. Зазначене формулює педагогічне завдання щодо підготовки викладачів ВВШ, яке полягає у моделюванні образу викладача ВВШ та процесу його досягнення.

Суб'єктне сприйняття ідеального образу викладача ВВШ, самооцінюванння та співставлення «Я ідеального» та «Я реального» створює умови для самодетермінації подальшого професійного розвитку. Сприйняття та усвідомлення власних ідеалів та потреб до професійної самореалізації слугує мотиваційною основою саморозвитку.

Проблема суб'єктності також знайшла своє широке відображення й у працях психологів. Зокрема С. Рубінштейном було запропоновано концепцію людини як суб'єкта діяльності. Він зазначав, що суб'єкт як активна сторона, діяч реалізує свою активність не тільки в зовнішній діяльності, а й у внутрішній діяльності, куди слід включати свідомість та самосвідомість. Крім того, С. Рубінштей вважав, що діяльність, яка визначає об'єкт, над яким вона проводиться, визначає тим самим i суб'єкта, який іiі здійснює; працюючи над об'єктом, суб'єкт визначає на тільки його, але й себе. [5, c. 437-438].

Значну увагу дослідженню суб'єкта у психології приділяв А. Брушлінський. Зокрема він зазначав, що «трактування людини як суб'єкта допомагає цілісно, системно розкрити ії специфічну активність в усіх видах взаємодії зі світом (практичної, суто духовної). 3 віком у житті людини все вагомішими стають саморозвиток, самовиховання, самоформування i відповідно більше приділення уваги внутрішнім умовам, через які завжди тільки і діють зовнішні впливи.» [1, с. 4].

Поняття «суб'єктність», він визначає як «...системну цілісність усіх іiі найскладніших i суперечливих якостей суб'єкта, насамперед психічних процесів, станів і властивостей його свідомості й несвідомого. Така цілісність формується у ході історичного й індивідуального розвитку. Будучи імманентно активним, людський індивід проте не народжується, а стає 
суб'єктом у процесі спілкування, діяльності й інших видів своєї активності» $[1$, c. 4].

Значну увагу питанням суб'єктності та суб’єкта у професійній та освітній діяльності приділив у своїх працях В.Ягупов. Зокрема, автор визначає суб'єктність як професійну важливу якість, сутність якої полягає у позитивному самосприйнятті та самовідноменні, а також самодетермінації та саморегуляції у професійній діяльності [8]. Щодо суб' єктності у навчанні інтегральним показником цього явища, В.Ягупов визначає - повну автономність у навчальній діяльності [9, с. 33].

На думку В. Осьодла, до числа особистісних якостей і професійних особливостей офіцерів, які виступають у ролі внутрішніх умов і визначають розвиток суб'єктності за відповідними структурними компонентами, відносяться: а) загальна рефлексивність, прогностичність, соціальний інтелект, а також досвід самовизначення в складних ситуаціях; б) загальна професійна освіченість, досвід позитивних життєвих і професійних досягнень, творчий потенціал, емоційно-вольова стійкість; в) загальна активність, мотивація досягнення, внутрішній локус контролю, схильність /прагнення до ризику, а також характер професійної Я-концепції офіцера, що оцінюється за параметрами спрямованості, індивідуального способу професійного зростання, прийняття себе як професіонала. [4, с. 204-205].

Аналіз наукових праць дав можливість встановити низку характеристик, що розкривають сутність поняття «суб'єктність» та класифікувати їх за зовнішньою та внутрішньою активністю прояву суб'єктності, зокрема до таких віднесемо:

внутрішні характеристики (свідомість та самосвідомість, воля);

зовнішні характеристики (позитивне самосприйняття та самовідношення, самодетермінація та саморегуляція, автономність, предметність, активність).

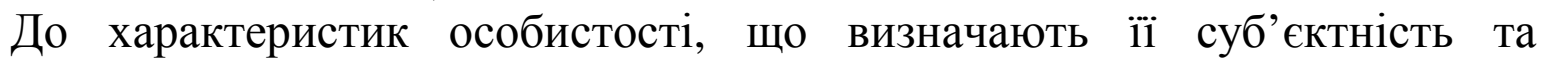
вказують на рівень іiі розвитку, відносять такі:

«активність - здатність до самоініціації діяльності, цілепокладання;

автономність і самостійність - здатність самовизначити свою активність, iii смислове зумовлення і ресурсне забезпечення;

відповідальність - добровільне взяття на себе гарантій щодо забезпечення результату, умов діяльності, рівня якості, готовність відповідати за наслідки;

рефлексивність - усвідомлення джерел власної активності, iіi процесу, результатів і способів корекції;

цілісність - здатність до функціонування як самоорганізована система; здатність розширювати межі свого «Я» відповідно до контексту, в якому відбувається активність;

самоцінність - здатність до прийняття себе; ставлення до себе як до цінності, самодостатності; 
креативність - здатність до створення нового, перетворення під час розв'язання суперечностей, розвитку соціальних відносин і саморозвитку» [3, c. 61].

В освітній діяльності для військового викладача його суб'єктність набуває вагомого значення, як для власної самореалізації так і для якісного навчання та виховання слухачів (курсантів). Викладач має прагнути використовувати i розвивати особистісні можливості для покращення педагогічній діяльності, підвищення іiі ефективності. Щоб військовий педагог міг використовувати основні ідеї теорії суб'єктності, а також на іiі засадах навчав слухачів (курсантів) як суб'єктів військово-професійної діяльності, необхідно знати характеристики суб'єкта та добирати ефективні методи для їх формування і розвитку.

До особистісних характеристик суб’ єктності викладача ВВШ відносимо такі:

Адекватна самооиінка та сприйняття дійсності. Військовий педагог бачать себе таким, який він $\epsilon$, а не таким, яким йому хочеться себе бачити. 3 об'єктивним сприйняттям пов'язано й те, що такі викладачі більш толерантні до протиріч та невизначеності. Вони схильні критично мислити та не бояться проблем, які не мають однозначних рішень.

Позитивне сприйняття себе та своїх учнів. Військовий педагог має позитивно сприймати себе та своїх вихованців 3 усіма притаманними їм сильними та слабкими сторонами, такими якими вони є насправді, без нестримної потреби повчати та контролювати інших.

Щирість та простота. Суб'єктність військового викладача проявляється у його внутрішній потребі у педагогічній діяльності. Мотиви, емоції, почуття щодо його діяльності безпосередні, не мають умовностей. Викладач бачить у своїх вихованцях ціль, а не засіб самоствердження, самореалізації.

Зосередженість на справі. Суб'єктною характеристикою $\epsilon$ сконцентрованість на педагогічній діяльності, улюбленій праці, відчуття обов'язку та відповідальності. Такий стан можливий коли людина і робота призначені одне для одного.

Самостійність. Викладач ВВШ прагне мати власний незалежний погляд на справу, а не покладається на думку інших. $\mathcal{C}$ активною силою, що чинить опір спробам нав'язати загальноприйняту позицію, критично оцінює ситуацію, робить власні висновки.

Орихінальне бачення. Військовий педагог здатний об'єктивно та 3 гідністю оцінити події, які іншим видаються звичними, буденними. Бачить у звичайних речах нове, рідко скаржиться на нудну, нецікаву роботу.

Усвідомлення суспільної значущості військово-педагогічної діяльності. Військовий педагог має щире бажання допомогти своїм вихованцям стати кращими, виявляє розуміння та симпатію до них, визначає суспільний інтерес як пріоритетний у своїй діяльності.

Схильність до суб'єкт-суб'єктних відносин. Викладачу ВВНЗ 
притаманні неупередженість у стосунках з вихованцями та повага до них.

Автономність. Педагог знаходиться у гармонії з середовищем в якому перебуває, проте зберігає внутрішню незалежність від нього. Він самостійний та впевнений у собі, тому мислення та поведінка не перебувають у залежності від соціального впливу. Здатний проявляти креативність у різних видах педагогічної діяльності.

Більшість викладачів вищої військової школи відчувають потребу у самовдосконаленні, прагнуть розкрити та реалізувати власний внутрішній потенціал. Але не всі можуть досягти цієї мети. Це пов'язано передусім із неспроможністю визначити власні здібності та задатки, невмінням їх визначити, а також тим, що не знають до чого прагнути у самовдосконаленні як педагога. Не менш важливим негативним чинником $є$ сумніви у своїх здібностях, що безумовно знижують можливості саморозвитку.

Таким чином, суб'єктність військового викладача, що грунтується на глибокому усвідомленні власного потенціалу та розумінні потреби професійного розвитку, є джерелом його активності в освітній діяльності на основі власного військово-професійного досвіду та максимальної реалізації творчого потенціалу. Досягнення суб'єктності це непростий шлях, що вимагає від викладачів постійної та наполегливої роботи над собою, проте забезпечує розвиток повноцінної, активної, позитивної, креативної постаті викладача вищої військової школи, ефективного організатора освітнього процесу.

Висновки. Аналіз наукових досліджень суб'єктності дозволяє зробити висновок, що спільним для всіх проаналізованих підходів $\epsilon$ розуміння суб'єктності як складного психологічного явища, що об'єднує у собі різні рівні прояву активності людини. Сучасне розуміння суб'єктності пов'язане 3 розумінням іï як міри становлення людини суб'єктом власного життя та професійної діяльності, а також як рівня розвитку свідомості щодо особистого самосприйняття.

Зазначені вище ознаки суб'єктності 3 урахуванням особливостей професійної діяльності військового педагога дають можливість визначити сутність суб'єктності викладача ВВШ як набутої у процесі навчання та педагогічної діяльності інтегральної якості, що проявляється в усвідомленій здатності до організації власної професійної діяльності, активній діяльності спрямованій на перетворення педагогічної дійсності та самого себе.

\section{ЛІТЕРАТУРА}

1. Брушлинский А.В. Проблема субъекта в психологической науке А.В. Брушлинский // Психол. журнал. — 1991. — М. 12. — №6. — С . 3-10.

2. Дюркгейм Э.О. Разделении общественного труда. Метод социологии / Э. Дюркгейм ; [под общ. ред. А. Б. Гофмана]. - М., 1991. - 468 с.

3. Осьодло В.І. Психологія професійного становлення офіцера : монографія / В.І. Осьодло. — К. : ПП «Золоті ворота», 2012. — 463 с.

4. Осьодло В.І. Суб'єктний підхід у психологічному супроводі професійного становлення офіцера // Психологія особистості / В.І. Осьодло. — К. 2013. — № 1(4). C. 204-213. Електронний ресурс — Режим доступу: http://ps.pu.if.ua/2013_4/22Osio.pdf 
5. Рубинштейн С.Л. Принцип творческой самодеятельности : Избранные философско-психологические труды / С.Л. Рубинштейн. - М., 1997. — 528 с.

6. Сартр Ж.П. Екзистенциализм - это гуманизм : Сумерки богов. - М. : Политиздат, 1989. - с. 319-344. Електронний ресурс - Режим доступу : http://darkelly.info/work/PD/sartr.ukr.pdf

7. Філософський енциклопедичний словник / за ред. В.І. Шинкарук Інститут філософії ім. Г.С. Сковороди НАНУ : Київ. - Абрис. - 2002. - 750 с.

8. Ягупов В.В. Формирование и развитие профессиональной субъектности офицеров / В.В. Ягупов, Н.А. Крышталь, В.Н. Король // Известия Российской академии образования. - 2013. - №1. - С. 74-83. Електронний ресурс - Режим доступу: http:/LIBRARY.RSU.EDU.RU/BLOG/WPCONTENT/UPLOADS/2015/03/ИЗВЕСТИЯРОССИЙСКОЙ-АКАДЕМИИ-ОБРАЗОВАНИЯ-2013-№-1.PDF

9. Ягупов В.В. Суб'єктність як основна детермінанта неперервної професійної освіти людини / В.В. Ягупов // Проблеми освіти: [науково-метод. зб.] / кол. авт. - К. : Наук.метод. центр вищої освіти, 2002. — Вип. 27. - С. 160-170.

\section{REFERENCES}

1. Brushlinskiy, A.V. (1991). Problema sub'ekta v psihologicheskoy nauke [The problem of the subject in psychological science]. Psihol. zhurnal, M., S. 3-10. (in Russian).

2. Dyurkgeym, E.O. (1991). Razdelenii obschestvennogo truda. Metod sotsiologii [The division of social labor. Method of sociology]. M., 468 s. (in Russian).

3. Osodlo, V.I. (2012). Psykholohiia profesiinoho stanovlennia ofitsera [Psychology of professional formation of an officer]. monohrafiia, K., PP «Zoloti vorota», 463 s. (in Ukrainian).

4. Osodlo, V.I. (2013). Subiektnyi pidkhid u psykholohichnomu suprovodi profesiinoho stanovlennia ofitsera [Subjective approach in psychological support of professional formation of an officer]. Psykholohiia osobystosti, K. (in Ukrainian).

5. Rubinshteyn, S.L. (1997.). Printsip tvorcheskoy samodeyatelnosti [Principle of creative initiative]. Izbrannyie filosofsko-psihologicheskie trudyi, M., 528 s. (in Russian).

6. Sartr, Zh.P. (1989). Ekzistentsializm - eto gumanizm : Sumerki bogov [Existentialism is humanism: Twilight of the gods]. M., Politizdat, s. 319-344. (in Russian).

7. Shynkaruk, V.I. (2002). Filosofskyi entsyklopedychnyi slovnyk [The Philosophical Encyclopedic Dictionary]. NANU, K., Abrys, 750 s. (in Ukrainian).

8. Yahupov, V.V. (2013). Formirovanie i razvitie professionalnoy sub'ektnosti ofitserov [Formation and development of professional subjectivity of officers]. Izvestiya Rossiyskoy akademii obrazovaniya. S. 74-83. (in Russian).

9. Yahupov, V.V. (2002). Subiektnist yak osnovna determinanta neperervnoi profesiinoi osvity liudyny [Subjectivity as the main determinant of continuous professional education of a person]. K., Nauk.-metod. tsentr vyshchoi osvity, S. 160-170. (in Ukrainian).

\section{PЕЗЮМЕ}

Олег Рыбчук,
Национальный университет обороны Украины
имени Ивана Черняховского

\section{Субъектность преподавателя высшей военной школы}

Статья посвящена проблеме становления преподавателей высшей военной школь как субъекта педагогической деятельности. На сегодняшний день в контексте реформирования Вооруженных Сил Украинь военное образование приобретает особое значение, а к профессионализму преподавателя высшей военной школь предъявляются высокие требования. Достижение высокого уровня профессионального развития 
военного педагога зависит от личного отношения $\kappa$ профессии и собственного самовосприятия в ней. В статье проанализированы философские, педагогические и психологические подходы $\kappa$ определению сущностных признаков субъектности. Определенные личностные характеристики субъектности преподавателя высшей военной школь. Результаты исследования дают возможность для выработки подходов к подготовке и повышению квалификаџии военных преподавателей, развития их субъектности.

Ключевые слова. Субъект; субъектность; деятельность; активность; преподаватель; образование; развитие.

\section{SUMMARY}

Oleh Rybchuk,

National Defence University of Ukraine named after Ivan Chernyahovskiy

\section{Subjectivity of higher military school teacher}

Introduction: The article is devoted to the problem of development of the higher military school teacher as a subject of pedagogical activity. As of now in the context of the Armed Forces of Ukraine reformation, military education is of great importance and there are high requirements for the professional lecturer of the military school. Achievement of high level of military school teacher professional development depends on the personal attitude to the profession and self-perception in the chosen profession. The article analyses philosophical, pedagogical and psychological approaches to essential subjectivity features development. Those higher military school teacher professional subjective characteristics are defined. The results of the research allows to develop the approaches to the preparation and enhancement of military teachers qualification and their subjectivity development.

The purpose the determination of essential characteristics of higher military school teachers' subjectivity.

Methods: The higher military school teacher subjectivity research was conducted using the methods of philosophical and scientific sources, devoted to the questions of personal development and those showing the essence of subjective active approach theoretical analysis; generalization and systematization of approaches to concept definition, also as subjectivity essential characteristics; synthesis and extrapolation of the scientific approaches to the definition of subjectivity to the activities the higher military school teacher.

Results: Subjectivity scientific researches analysis allows to conclude that understanding of subjectivity as a complex psychological phenomenon is common. This phenomenon unites different levels of human activity. Modern understanding of subjectivity is connected to understanding it as a measure of human becoming a subject of his/her own life and professional activity and as a level of consciousness development towards self-perseption.

Originality: The originality of this research lies in the definition of the peculiarities of the higher military school teacher subjectivity manifestation.

Conclusion: Above mentioned subjectivity characteristics including the peculiarities of military teacher professional activity allows to determine the essence of higher military school lecturer subjectivity as an integral feature, acquired in the process of studying and pedagogical activity, which manifests in conscious ability to organize professional activity and activities, aimed at the transformation of pedagogical actuality and the self.

Key words: subject; subjectivity; practice; activity; teacher; education; development. 